\title{
Pozitif Değerler Ölçeğini Türk Kültürüne Uyarlama Çalışması
}

DOI: $10.26466 /$ opus.395104

\author{
Nihan Arslan* \\ * Dr. Öğr. Üyesi, FSM Vakıf Üniversitesi, Eğitim Fakültesi, İstanbul/Türkiye \\ E-Posta: narslan@fsm.edu.tr \\ ORCID: 0000-0002-2451-0852
}

\section{Öz}

Çalışmada, Huang ve Cornell (2016) tarafından geliştirilen Pozitif Değerler Ölçeği (PDÖ) Türkçeye uyarlama çalışmasının yapılması amaçlanmıştır. Ölçeğin Türkçe formu 315 orta okul öğrencisi ile çalışılmıştır. Araştırma sürecinde; 9 maddeden ve iki alt ölçekten oluşan Pozitif Değerler Ölçeği'nin derecelendirmesi 6'lı Likert üzerinden yapılmaktadır. Ölçeğin Cronbach Alfa katsayısı .88 olarak hesaplanmıştır.Ölçek uyarlama analizi çalışmasında iki boyutlu model ortaya çlkmaktadır $\left(x^{2}=58.77, s d=26, p=0.06, \quad R M S E A=.06, N F I=.97, N N F I=.98, C F I=.98, \quad\right.$ IFI=.98, RFI=.96, ve SRMR=.36). Pozitif değerler ölçeğinin Türkçe formunun uygulandiğı orta okul örnekleminde güvenilir ve geçerli istatistiki değerler aldığı sonucuna ulaşılmıştır.

Anahtar Kelimeler: Değer, Pozitif Değer, Ortaokul öğrencisi

OPUS @ C Uluslararası Toplum Araştırmaları Dergisi-International Journal of Society Researches ISSN:2528-9527 E-ISSN : 2528-9535

http://opusjournal.net 
ISSN:2528-9527

E-ISSN : 2528-9535

Yll Year: 8

Cilt Volume: 8

Sayı Issue : 14

Uluslararası Toplum Araştırmaları Dergisi International Journal of Society Researches

Nisan April 2018

Makalenin Gelis Tarihi Received Date: 14/02/2018 Makalenin Kabul Tarihi Accepted Date: 10/03/2018

\title{
Adaptation of the Scale of Positive Values to Turkish Culture
}

\begin{abstract}
In this study, it was aimed to make adaptation of the Positive Values Scale (PDU) developed by Huang and Cornell (2016) to Turkish culture. The Turkish form of the scale was studied with 315 middle school students. In the research process, the rating of the scale of Positive Values consisting of 9 items and two sub-scales is made on the 6 th response options. The Cronbach alpha coefficient of the scale was calculated as .88. A two-dimensional model emerges in the analysis of scale adaptation $\left(x^{2}=58.77, s d=26, p=0.06, R M S E A=.06, N F I=.97, N N F I=.98, C F I=.98, I F I=.98, R F I=.96\right.$, ve $S R M R=.36$. It was concluded that the Turkish form of the positive values scale obtained reliable and valid statistical values in the middle school sample.
\end{abstract}

Keywords: Values, Positive values, Middle school students.

OPUS @ C Uluslararası Toplum Araştırmaları Dergisi-International Journal of Society Researches ISSN:2528-9527 E-ISSN : 2528-9535

http://opusjournal.net 


\section{Giriş}

Değerler bireyin yaşamında yol gösterici ilkeler olarak hizmet ederler. Rokeach değerleri yaşamdaki belirli olayların sonuçlarının bireysel ya da toplumsal olarak kabul görüp görmediğini ifade eden inançlar olarak tanımlamıştır (Myyry, Juujärvi ve Pesso, 2013). Schwartz (1992) değerleri davranışa rehberlik eden ilkeler olarak tanımlamaktadır (Bozgeyikli,2010; Myyry, Juujärvi ve Pesso, 2013). Değerler ve ahlaki gelişim ile ilgili psikoloji alanındaki bilim adamları tarafından farklı görüşler öne sürülmüştür. Freud'a göre ahlaki gelişim ve değerlerin gelişmesi fallik dönemde, baba ile özdeşleşme sonucunda meydana gelir. Çocuğun davranışlarını yönlendirmesi ve toplumsal rolleri benimsemesi süper ego aracılığıyla öğrendiği standartlara göre olur (Çağdaş ve Seçer,2002). Erikson’a göre ergenlik dönemi sadece "ben kimim" ve "ne olmak istiyorum" sorusunun cevap arandığı dönem değil aynı zamanda kişisel değer sisteminin ve yaşam felsefesinin oluştuğu bir dönemdir (Hillaker,2004). Sosyal öğrenme kuramına göre ise ahlaki değerler model alma yoluyla kazanılmaktadır (Mercin, 2005). Çocuklar anne-babalarının birçok davranışını örnek alırken, aynı zamanda ahlaki değer ve standartların da benimserler (Morgan, 1990).

Piaget ise bilişsel gelişim ile ahlaki gelişim arasında paralellik olduğunu savunmuştur (Jersild,1983). Kohlberg (1983) ise Piaget'in kuramını yeniden incelemiş, bireyin bilgisi arttıkça, ahlaki gelişiminde ilerleme olduğunu söylemiştir. Gilligan da(1998) ahlak gelişimi ile ilgili çalışmış, Kohlberg'i sadece erkekler üzerinden genellemeler yaptığı için eleştirmiştir. Harris ve Liebert (1991) çocukların kendi gelişimlerinde aktif bir rol oynadığını iddia etmiştir (Haljasorg ve Lilleoja,2016). Schwartz (1992) değerleri yol gösterici ilkeler olarak tanımlamıştır ve on evrensel değer belirlemiştir. Bunlar hedonizm, öz-düzenleme, uyum, güvenlik, evrensellik, yardımseverlik, gelenekçilik, güç, başarı, teşviktir. Scwartz'ın yaklaşımına göre değerler özel çeşit inançlardır (special kinds of beliefs) ve diğer inançları düzenlerler. Okul ortamı genç yaşta pek çok çocuk tarafından yaşam süreci içerisinde ilk deneyimlerin elde edildiği geleneksel bir kurum olmaktadır (Dulli, 2006). Okul iklimi okuldaki bireylerin değerlerini ve prososyal davranışlarını içerir. Pozitif değerlerin ve prososyal davranışların güçlü olduğu okullar olumlu okul ortamının 
sonucu olarak görülebilir (Domino,2013). Değerlerin geliştirilmesi ve uygulanması için tasarlanmış bir okul programının uygulandığı bir çalışmada olumlu davranışların arttığı ve devamsızlık oranlarının azaldığ1 görülmüştür (Christofferson ve Callahan,2015). Okulun genel değer ve inanç sistemi gibi geniş yapıları içine alan çalışmalarda öğretmen-öğretmen ve öğretmen-öğrenci çatışmasına sahip okullara giden öğrencilerin (6-16 yaş) davranış problemlerinde anlamlı derecede daha yüksek artışlar yaşadığı, ancak diğer yandan öğrenmeyi vurgulayan "iyi organize olmuş uyumlu okullara" gidenlerin ise bu sonuçlarda düşüş yaşadığı sonucuna ulaşılmıştır (Dulli, 2006). Çatışma oranı yüksek olan okullara giden öğrencilerin, altı yıl sonra alkol kullanımına ve suç işlemeye yönelik daha yüksek risk taşıdığı sonucuna ulaşılmıştır (Kasen, Berenson, Cohen ve Johnson, 2004). Okullarda olumlu bir disiplinin sürdürülmesi, herkes tarafından anlaşılan diyalog süreci ve inşa edilmiş sağlam bir değer tabanı gerektirir (Preez ve Roux,2010). Pozitif değerler ve öz yeterlik gelişmesinde ebeveynler oldukça önemli rol oynarlar. Yapılan araştırmalar ebeveynlerinden duygusal destek alan ergenlerin başarılı kimlik geliştirdiğini göstermiştir (Sartor ve Youniss,2002; Hillaker,2004). Sosyal destek pozitif değerlerin gelişmesine ve benlik saygısına etki eder. Sosyal destek sayesinde birey sadece kendi isteklerini değil başkalarının isteklerini de göz önünde bulundurarak hareket eder (Goodwin, Cost ve Adanu,2004). Sosyalleşme süreci ailede başlar, okulda devam eder, dolayısıyla ailenin yanı sıra okullar da bireylerin değer yapılarını şekillendirmede oldukça önemli bir yere sahiptir (Gill,1997). Değerler eğitimi çocuğun gelişim dönemine uygun bir şekilde verilmelidir (Haljasorg ve Lilleoja,2016). Huang ve Cornell (2016) pozitif değerleri iki boyutta ele almışlardır. Birinci boyutta bireysel sorumluluklar ele alınmış; (doğruyu söylemek, doğru olanı yapmak gibi), ikinci boyutta ise bireyin başkalarına karşı sorumlulukları olarak ele alınmıştır (diğerlerine karşı saygılı ve nazik olmak gibi).

Bu çalışmada Huang ve Cornell (2016) tarafından geliştirilen Pozitif Değerler Ölçeği'nin Türkçeye uyarlama çalışmasının yapılması amaçlanmıştır. Pozitif değerler ölçeği okul iklimi ilgili yapılan araştırmalarda kullanılabilir. Öğrencilerin ileri sosyal davranışlarının ve pozitif değerlerin desteklendiği okullar olumlu okul ikliminin göstergesi olarak yorumlanabilir (Huang ve Cornell, 2016). 


\section{Yöntem}

\section{Çalışma Grubu}

Huang ve Cornell, (2016) in geliştirmiş olduğu "Pozitif Değerler" ölçeği ortaokul öğrencileri üzerinde çalışılmıştır. Pozitif değerler ölçeği 315 ortaokul öğrencisine uygulanmıştır. Araştırma verileri Sakarya ilinde toplanmıştır. Araştırma kapsamında örneklemin 154' (\% 49) ü kız, 161 (\%51)'i erkek öğrenciden oluşmaktadır. Araştırmanın örneklemi 157 ( \%48) yedinci sınıf öğrencisi, 163 (\% 52) sekizinci sınıf öğrencisinden oluşmaktadır. Örneklemin yaş ortalaması 12.9' dur.

Pozitif Değerler Ölçeği: 9 maddeden ve iki alt ölçekten oluşan Pozitif Değerler Ölçeği'nin (Huang ve Cornell, 2016), derecelendirmesi 6'lı Likert üzerinden yapılmaktadır. Ölçeğin güvenirlik katsayısı .88 olarak hesaplanmıştır. Ölçek uyarlama çalışması kapsamında, ölçeğin İngilizce formu, araştırmacı tarafından Türkçeye çevrilerek alanında uzman öğretim üyelerinden görüş alınmıştır. Araştırma kapsamında, doğrulayıcı faktör analizi, düzeltilmiş madde-toplam korelâsyonu ve güvenirliği incelenmiştir.

\section{Bulgular}

\section{Madde Analizi ve Güvenirlik}

PDÖ'nün korelasyon katsayılarının .52 ile .75 aralığında değiştiği bulunmuştur. Tablo 1'de analiz sonucu yer almaktadır.

Tablo 1. PDÖ Maddelerinin Korelasyon Puanlar

\begin{tabular}{cccc}
\hline Madde No & rjx & Madde No & rjx \\
\hline 1 & .52 & 7 & .64 \\
2 & .75 & 8 & .60 \\
3 & .61 & 9 & .67 \\
4 & .59 & & \\
5 & .62 & & \\
6 & .58 & & \\
\hline
\end{tabular}


Ölçeğin tamamı için Cronbach's $(\alpha)$ katsayısı .88 olarak bulunmuştur.

\section{Yapı Geçerliği}

PDÖ'nün analizi sonucunda $\left(\mathrm{x}^{2}=58.77, \mathrm{sd}=26, \mathrm{p}=0.06\right.$, RMSEA=.06, (NFI) $=0.97,(\mathrm{NNFI})=0.98, \mathrm{SRMR}=0.036)$ iki boyutlu modelin iyi uyum verdiğini göstermektedir ( $\mathrm{Hu}$ ve Bentler, 1999). Analiz sonucuna ait standartlaştırılmış regresyon ağırlıkları Şekil 1'de verilmiştir:

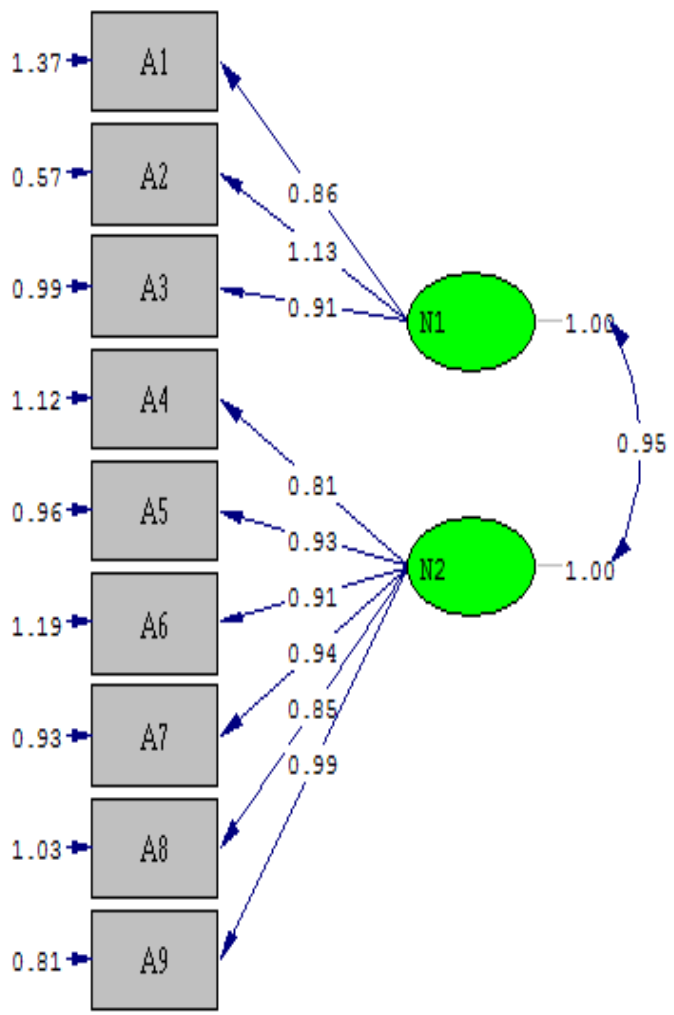

Chi-Square $=58.77, d f=26, \mathrm{P}-\mathrm{value}=0.00024, \mathrm{RMSEA}=0.063$ 


\section{Tartışma}

Araştırmada, Huang ve Cornell (2016) tarafından geliştirilen Pozitif Değerler Ölçeği'nin Türk kültürüne uyarlanarak alan çalışmalarında kullanılması amaçlanmıştır. PDÖ'nün ölçümlerinden yapılacak yorumların yapı geçerliğini test etmek için DFA'dan yararlanılmıştır. DFA'da ulaşılan bulgular, PDÖ’ye ilişkin iki faktörlü yapıya ait uyum indekslerinin yeterli olduğunu göstermiştir. Analiz sonucunda ortaya çıkan uyum indeksleri ölçeğin bütünü ve alt boyutları arasındaki ilişkinin kuramsal yapıyı açıladığı görülmektedir. Alan yazında pozitif değer kavramı ile ilgili ölçek çalışmaları incelendiğinde, yapılan araştırmanın bulgularını destekleyici nitelikte ulusal ve uluslararası alanda yapılan çalışmalar dikkat çekmektedir. Kim, Atkinson ve Yang (1999) "Asya Değerler Ölçeği” geliştirdikleri çalışmada etnik kültürel değerleri ölçen araç eksikliğine vurgu yapmıştır. İki farklı çalışma sonucunda iç tutarlılık katsayıları .81 ve .82 olarak bulunmuştur. Ölçekten alınan toplam puan Asya kültüründeki değerleri yansıtmaktadır. Asya kültürüne ait olan yüksek derecede güvenilirlik bulguları araştırmanın sonucunu destekler niteliktedir. Ulusal literatürde yapılan çalışmalar açısından, Bolat (2013) altı alt boyuttan oluşan çok boyutlu sosyal değerler ölçeğini geliştirmiştir. Bu boyutlar aile değerleri, bilimsel değerler, çalışma-iş değerleri, dini değerler, geleneksel değerler ve siyasi değerler olmak üzere araştırmanın alt boyutları ile uyum göstermektedir. Asan, Ekşi, Doğan ve Ekşi (2008) bireysel değerler envanteri uyarlama çalışması yapmışlardır. Yapılan çalışma sonucunda, ölçeğin iç tutarlılık ve faktör yüklerinin Türk kültürüne uygun olduğu gözlemlenmiştir. Yapılan analiz sonuçları Kişisel Değerler Envanteri'nin yüksek düzeyde geçerlik ve güvenirliğe sahip olduğunu görülmektedir. Yapılan araştırma sonucunda ileride yapılacak çalışmalara öneriler olarak; elde edilen pozitif değerler ölçeği ile ülke çapında tüm ortaokul öğrencilerine yönelik karşılaştırmalı çalışmalar yürütülebilir. Çalışma, ortaokul yedinci ve sekizinci sinifta okuyan katılımcilar ile gerçekleştirilmiştir. Lise ve üniversite öğrencilerini de içine alarak yapılacak uyarlama çalışmalarından elde edilecek sonuçların, bu çalışmada elde edilen sonuçlarla karşılaştırılması ölçeğin güvenilirlik ve geçerliliğine katkı sağlayabilir. Pozitif değerler ölçeği okul iklimi ilgili 
yapılan araştırmalarda kullanılabilir. Pozitif değerlerin desteklenmesi olumlu bir okul ikliminin göstergesi olarak yorumlanabilir (Huang ve Cornell, 2016). Bu açıdan ele alındığında, öğretmenlere yönelik öneriler kapsamında, okullarda değerler eğitimi çalışmalarına daha fazla önem gösterilmesinin yanında öğrencilerinin ahlaki gelişimlerinin desteklenmesi sağlanabilir. Pozitif değerler ölçeğinin eğitim bilimleri alanında çalışan uzmanlara, psikologlara ve psikolojik danışmanlara 1şık tutacağı düşünülmektedir. Pozitif değerler ölçeğinin ölçüt geçerliliğinin sağlanabilmesi açısından farklı ölçeklerle beraber akademik çalışmalarda kullanılması önerilmektedir. Pozitif değerler ölçeği ile ülkemizde yer alan ortaokul öğrencilerini içeren karşılaştırma çalışmaları yapılabilir. Ayrıca, demografik değişkenler kullanılarak öğrencilerin pozitif değer düzeylerinin farklılaşıp farklılaşmadığı araştırılabilir. 


\title{
EXTENDED ABSTRACT
}

\section{Adaptation of the Scale of Positive Values to Turkish Culture}

\author{
Nihan Arslan \\ FSM Vakıf University
}

\section{Introduction}

Values serve as guiding principles in the individual's life. Rokeach defines values as beliefs that indicate whether the consequences of certain events in life are considered individual or social (Myyry, Juujärvi ve Pesso, 2013). Schwartz (1992) defines values as guiding principles to behavior. Scientists have suggested different views on values and moral development in psychology. According to Freud, moral development and development of values occur in the phallic period as a result of identification with the father. The child's orientation and adoption of social roles are based on the standards he / she has learned through super ego (Çağdaş ve Seçer, 2002). According to Erikson, adolescence is not only the period when the question "Who am I" and "what am i supposed to be" is sought. It is also a period of personal value system and life philosophy (Hillaker,2004). According to the theory of social learning, moral values are acquired through model taking (Mercin, 2005). Children take examples of many behaviors of their parents. They also adopt moral values and standards (Morgan, 1990). Piaget argued that there is parallelism between cognitive development and moral development (Jersild,1983). Kohlberg (1983) reviewed Piaget's theory, saying that as the individual's knowledge increased, there was progress in moral development. Gilligan has also worked on moral development(1998). He criticized Kohlberg for making generalizations over men only. Harris and Liebert (1991) claimed that children played an active role in their development (Haljasorg and Lilleoja,2016). Schwartz (1992) defines values as guiding principles and sets ten universal values. These are hedonism, self-regulation, harmony, 
security, universality, charity, traditionalism, power, success, incentives. According to Scwartz's approach, values are special kind of beliefs and they regulate other beliefs. School environment is a traditional institution where first experiences are obtained by many young children during the life process (Dulli, 2006). School climate includes values of individuals in school and prosocial behavior. Schools where positive values and prosocial behavior are strong can be seen as a result of positive school environment (Domino,2013). A study of a school program designed to develop and implement values has shown that positive behaviors are increasing and absenteeism rates are decreasing (Christofferson and Callahan,2015). In studies involving large structures such as the school's general value and belief system, there were significantly higher increases in behavior problems of students who went to schools with teacherteacher-student conflict (6-16 years) (Dulli, 2006). It was concluded that students who went to schools with high conflict rates had a higher risk of alcohol use and crime after six years (Kasen, Berenson, Cohen and Johnson, 2004).

Method: Huang and Cornell, (2016) studied the "positive values" scale of secondary school students. Positive values scale was applied to 315 middle school students. Research data were collected in Sakarya province. Within the scope of the research, the sample consists of 154 (49\%) female, 161 (51\%) male students. The sample consisted of 157 (48\%) seventh grade students, 163 (52\%) eighth grade students. The mean age of the sample is 12.9 .

Structure Validity: As a result of the analysis of the Positive Values Scale $\left(\mathrm{x}^{2}=58.77, \mathrm{df}=26, \mathrm{p}=0.06, \mathrm{RMSEA}=.06,(\mathrm{NFI})=0.97,(\mathrm{NNFI})=0.98, \mathrm{SRMR}=\right.$ 0.036) shows that the two-dimensional model fits well ( $\mathrm{Hu}$ and Bentler, 1999).

\section{Conclusion and Discussion}

In this study, the Positive Values Scale developed by Huang and Cornell (2016) was adapted to Turkish culture and used in field studies. A confirmatory factor analysis was used to test structure validity from the 
measurement of the Positive Values Scale. The results obtained as a result of confirmatory factor analysis show that the two-factor conformation indexes for the positive values scale are sufficient. It is observed that the relationship between the whole scale and its sub-dimensions reveals the theoretical structure. When the scale studies on the concept of positive value are examined in the field of literature, the national and international studies that support the findings of the research. Kim, Atkinson and Yang (1999) highlighted the lack of tools to measure ethnic cultural values in the study they developed on the "Asian Values Scale". Internal consistency coefficients as a result of two different work found as .81 and .82 . The total score from the scale reflects the values of Asian culture. As a result of the research, as suggestions for future studies; comparative studies for all secondary school students across the country can be carried out with the scale of the positive values obtained. The study was carried out with the participants who were in the seventh and eighth grade of secondary school. The results obtained from adaptation studies involving high school and university students can contribute to the reliability and validity of the scale.

\section{Kaynakça / References}

Asan, T., Ekşi, F., Doğan,A., ve Ekşi, H. (2008). Bireysel değerler envanteri'nin dilsel eşdeğerlik geçerlik ve güvenirlik çalışması. Marmara Üniversitesi Atatürk Ĕ̆itim Fakültesi Eğitim Bilimleri Dergisi, 27, 15-38.

Bolat, Y. (2013). Bir değer ölçme aracı: Çok Boyutlu Sosyal Değerler Ölçeği. Turkish Journal of Education, 2 (4), 13-27.

Bozgeyikli, H.(2010). The relationship between high school students' psychological needs and human value perceptions. Procedia Social and Behavioral Sciences, 9, 1798-1804.

Christofferson, R.D. ve Callahan, K. (2015). Positive behavior support in schools (PBSIS): An administrative perspective on the implementation of a comprehensive school-wide intervention in an urban charter school. Education Leadership Review of Doctoral Research, 2(2), 35-49. 
Çağdaş, A. ve Seçer,Z. (2002). Çocuk ve ergende sosyal ve ahlak gelişimi. Ankara: Nobel Yayınları.

Domino, M. (2013). Measuring the impact of an alternative approach to school bullying. Journal of School Health, 83, 430-437. doi:10.1111/josh.12047.

Dulli,S.L. (2006). Primary socializ ation theory and bullying: the effects of primary sources of socialization on bullying behaviors among adolescents. University of North Carolina, Doctor of Philosophy.

Gill, R. (1997). Socialization. In Dictionary of ethics, theology and society, 772775. London and New York: Routledge.

Gilligan, C. (1998). In a different voice: psychological theory and women's development. Cambridge, Mass., London: Harvard University Press

Goodwin,R., Cost P. ve Adonu, J. (2004). Social support and its consequences: 'Positive' and 'deficiency' values and their implications for support and self-esteem. British Journal of Social Psychology, $43,1-10$.

Haljasorg, H. ve Lilleoja,L (2016). How could students become loyal citizens? basic values, value education, and national attitudes among 10th-graders in Estonia. Trames, 20(2) , 99-114.

Harris, J. R. and R. M. Liebert (1991). A contemporary view of development. New Jersey: Prentice Hall College Div.

Hillaker, B.D. (2004). The relationship of family-related developmental assets to positive values and social competencies (Master of Science). Department of Family and Child Ecology, Michigan State University.

Huang, F.L., ve Cornell, D. G. (2016). Using multilevel factor analysis with clustered data: Investigating the factor structure of the positive values scale. Journal of Psychoeducational Assessment, 34(1), 314.

Hu, L., ve Bentler, P. M. (1999). Cutoff criteria for fit indexes in covariance structural analysis: Conventional criteria versus new alternatives. Structural Equation Modeling, 6 (1), 55-65.

Jersild, A. (1983). Çocuk psikolojisi, Çev., Gülseren Günçe, 4. Baskı, Ankara Üniversitesi Eğitim Bilimleri Fakültesi Eğitim Araştırmaları Merkezi (EFAM) Yayını No:4, Ankara. 
Kasen, S., Berenson, K., Cohen, P., ve Johnson, J. G. (2004). The effects of school climate on changes in aggressive and other behaviors related to bullying. Lawrence Erlbaum Associates.

Kim, B. S., Atkinson, D. R., ve Yang, P. H. (1999). The asian values scale: Development, factor analysis, validation, and reliability. Journal of Counseling Psychology, 46(3), 342-352.

Mercin, L. (2005). Piaget ve Kohlberg'in ahlak gelişim kuramlarının özellikleri ve karşılaştırılması. SBArD Dergisi, 5, 73- 86.

Morgan, C. T. (1990). Psikolojiye giriş, Çev., H. Arıcı ve diğerleri, Hacettepe Üniversitesi Psikoloji Bölümü Yayınları, Ankara.

Myyry,L., Juujärvi,S. ve Pesso,K. (2013). Change in values and moral reasoning during higher education. European Journal of Developmental Psychology, 10 (2),269-284.

Preez, P. ve Roux, C. (2010). Human rights values or cultural values? pursuing values to maintain positive discipline in multicultural schools. South African Journal of Education, 30 (1), 13-26.

Sartor, C.E. ve Youniss, J. (2002). The relationship between positive parental involvement and identity achievement during adolescence. Adolescence, 37 (146), 221.

Schwartz, S. (1992). Universals in the content and structure of values: Theoretical advances and empirical tests in 20 countries. In M. P. Zanna (Ed.), Advances in experimental social psychology, (Vol. 25, pp. 1-65). San Diego, CA: Academic Press.

\section{Kaynakça Bilgisi / Citation Information}

Arslan, N. (2018). Pozitif değerler ölçeğini Türk kültürüne uyarlama çalışması. OPUS - Uluslararası Toplum Araştırmaları Dergisi, 8(14), 240-252. DOI: 10.26466/opus.395104 